H A R VAR D

\title{
Multinational Strategies and Developing Countries in Historical Perspective
}

\author{
Geoffrey Jones
}

\section{Working Paper}

10-076 


\section{Overview}

This working paper offers a longitudinal and descriptive analysis of the strategies of multinationals from developed countries in developing countries. The central argument is that strategies were shaped by the trade-off between opportunity and risk. Three broad environmental factors determined the trade-off. The first was the prevailing political economy, including the policies of both host and home governments, and the international legal framework. The second was the market and resources of the host country. The third factor was competition from local firms. The impact of these factors on corporate strategies is explored, as shown in Fig. 1, during the three eras in the modern history of globalization from the nineteenth century until the present day. The performance of specific multinationals depended on the extent to which their internal capabilities enabled them to respond to these external opportunities and threats. author. 
Fig. 1 Multinational Strategies in Developing Countries in the Three Eras of Globalization

\begin{tabular}{|c|c|c|c|}
\hline Opportunity/Risk & $\begin{array}{l}\text { First Global } \\
\text { Economy 1850-1929 }\end{array}$ & $\begin{array}{l}\text { De-Globalization } \\
\text { 1929-1978 }\end{array}$ & $\begin{array}{l}\text { Second Global } \\
\text { Economy } 1978 \text { - }\end{array}$ \\
\hline Political Economy & $\begin{array}{l}\text { High receptivity; } \\
\text { international law and } \\
\text { imperialism support } \\
\text { Western firms }\end{array}$ & $\begin{array}{l}\text { Expropriation; Import } \\
\text { Substitution; } \\
\text { exchange controls }\end{array}$ & $\begin{array}{l}\text { Liberalization, but } \\
\text { sovereign and } \\
\text { assertive governments }\end{array}$ \\
\hline $\begin{array}{l}\text { Markets and } \\
\text { Resources }\end{array}$ & $\begin{array}{l}\text { Low income; cultural } \\
\text { differences; vast } \\
\text { natural resources }\end{array}$ & $\begin{array}{l}\text { Limited convergence; } \\
\text { foreign ownership } \\
\text { restricted. }\end{array}$ & $\begin{array}{l}\text { Globalization; } \\
\text { tribalization; low cost } \\
\text { labor }\end{array}$ \\
\hline Competition & Embryonic & $\begin{array}{l}\text { State-owned } \\
\text { companies; private } \\
\text { enterprise curbed }\end{array}$ & $\begin{array}{l}\text { Growing private- } \\
\text { sector }\end{array}$ \\
\hline Strategies & $\begin{array}{l}\text { Co-opt local elites as } \\
\text { partners; seek home } \\
\text { country support; } \\
\text { overcome logistical } \\
\text { challenges }\end{array}$ & $\begin{array}{l}\text { Divest; invest in } \\
\text { West; forced } \\
\text { negotiations; joint } \\
\text { ventures and local } \\
\text { participation }\end{array}$ & $\begin{array}{l}\text { Access low labor } \\
\text { costs; adapt to local } \\
\text { markets and politics }\end{array}$ \\
\hline
\end{tabular}

Although important insights can be obtained from long-run perspectives, it should be noted from the outset that it presents major definitional issues. Countries have shifted between

Working papers are in draft form. This working paper is distributed for purposes of comment and discussion only. It may not be reproduced without permission of the copyright holder. Copies of working papers are available from the author. 
the "developing" and "developed" categories over time. Japan is the most obvious example, given its progression from developing status in the first global economy to the world's second largest economy in the contemporary global economy. However in the second global economy, the terms “developing” and “emerging” are used loosely, with countries such as Singapore and South Korea typically included in the category despite their level of economic development. For the purposes of this paper, developing countries are defined simply as beyond the West and (after 1950) Japan. It is readily acknowledged that deeper analysis would require a typology of countries to be employed.

\section{Multinational Strategies in Developing Countries in the First Global Economy, c1850-c1929.}

If we use a broad definition of globalization such as that proposed by Guillen - "as a process leading to greater interdependence and mutual awareness....among economic, political and social units in the world” - then globalization has a long history. ${ }^{1}$ The dramatic geographical expansion of the ancient Roman Empire, or of Islam centuries later, or the Mongol Empire of the thirteenth and fourteenth centuries, were manifestations of globalization trends. The Voyages of Discovery by Columbus and de Gama from Europe over five hundred years ago saw transfers of technology - and disease - never seen before.

Yet a combination of high transport costs, wars and government-imposed barriers handicapped the "process of greater interdependence". This changed in the nineteenth century, with radical improvements in transport and communications and the withdrawal of the state from

Copyright $@ 2010$ by Geoffrey Jones

Working papers are in draft form. This working paper is distributed for purposes of comment and discussion only. It may not be reproduced without permission of the copyright holder. Copies of working papers are available from the author. 
economies, including trade regulation. As the nineteenth century progressed, there were unprecedented flows of people, capital and trade, and unprecedented integration of markets. ${ }^{2}$ Business enterprises were key to globalization. Firms put in place a global banking and trading infrastructure. A global transportation and communications network was built by cable, and telegraph and shipping companies. Manufacturers transferred the production of goods ranging from sewing machines to automobiles and aspirins internationally. While World War 1 (19141918) exercised a major political and economic shock, globalization persisted through the 1920s, only to undergo a major meltdown in the wake of the Great Depression. ${ }^{3}$

Globalization was probably accompanied by a sharp rise in income inequality between the West and the rest of the world. In the mid-eighteenth century the income gaps between people in different parts of the world was probably quite small. Thereafter, in the words of Kenneth Pomeranz, there was a Great Divergence. ${ }^{4}$ This process was associated with the shift of manufacturing from East to West. By 1850 modern industrialization in textiles, iron and steel, engineering and shipbuilding in particular was well-advanced in parts of Western Europe and North America. The Industrial Revolution fundamentally shifted the cost structure in the world textile industry, to such an extent that Britain accounted for over 40 per cent of world exports of manufactured goods by the middle of the century. Although the timing and scale of this divergence, let alone its cause, continues to generate debate, it is evident that by 1914 there were large income differences between the “developed world”, primarily Western Europe and North America, alongside countries settled by their emigrants such as Argentina and Australia, and the

Copyright (C) 2010 by Geoffrey Jones

Working papers are in draft form. This working paper is distributed for purposes of comment and discussion only. It may not be reproduced without permission of the copyright holder. Copies of working papers are available from the author. 
rest of the world, including the once-great handicraft manufacturing nations of India and China. There is also some evidence that inequality within regions such as Latin America increased rapidly as globalization got under way in the second half of the century. ${ }^{5}$

There was massive investment by Western firms in the developing world during this first era of globalization. Foreign direct investment reached high levels relative to the size of the world economy - and majority of it was in developing countries (see Table 1). The drivers of this investment are wel1-understood. As the Western world industrialized and urbanized, firms launched a search for the minerals, commodities, and foodstuffs needed by the developed world, and constructed the physical and services infrastructure needed to exploit them. The low incomes of the non-Western world meant that they were of little interest as markets, except for basic clothing. Famously, exports of British and other Western textiles flooded into India and other countries, helping to decimate their traditional textile industries.

Copyright $@ 2010$ by Geoffrey Jones

Working papers are in draft form. This working paper is distributed for purposes of comment and discussion only. It may not be reproduced without permission of the copyright holder. Copies of working papers are available from the author. 
Table 1 Multinational Investment in Developing Countries 1914-2007

\begin{tabular}{|l|l|l|l|}
\hline & $\begin{array}{l}\text { World FDI Stock } \\
\text { (\$ billion) }\end{array}$ & \% World Output & $\begin{array}{l}\text { \% in developing } \\
\text { countries }\end{array}$ \\
\hline 1914 & 14 & 9.0 & 63 \\
\hline 1960 & 54 & 4.4 & 32 \\
\hline 1980 & 551 & 4.8 & 22 \\
\hline 1990 & 1,941 & 8.5 & 27 \\
\hline 2007 & 15,602 & 27 & 29 \\
\hline
\end{tabular}

Source: Dunning and Lundan, Multinationals, p. 175; World Investment Report (2008), pp.10, 257-60;

The strategies of Western firms benefitted from favorable conditions in this era. The spread of Western imperialism dramatically reduced the political risks of doing business in colonies. By the late nineteenth century European colonial governments rarely acted as direct agents of Western firms, and their general impact is better seen as improving the environment for all entrepreneurs, both because of improved institutions and investment in infrastructure. Yet by imposing and enforcing Western laws they made it much safer for Western firms to invest. Copyright (C) 2010 by Geoffrey Jones

Working papers are in draft form. This working paper is distributed for purposes of comment and discussion only. It may not be reproduced without permission of the copyright holder. Copies of working papers are available from the author. 
Oftentimes they awarded such firms huge concessions as incentives to invest in territories whose infrastructure was completely undeveloped and whose terrains were often challenging. A classic instance was when the colonial government gave the British soap manufacturer Lever Brothers an exclusive concession over a huge area of the Belgian Congo in 1911, which was intended to be used as plantations to supply the company with palm oil. ${ }^{6}$

In countries which were not formal colonies, local governments were even more desperate to attract modern technology and skills, as economic development offered the only way to resist the power of the Western nations. Western firms were able to negotiate exclusive and very favorable concessions with local political elites, who often preferred to award such contracts to foreign entrepreneurs rather than build up domestic rivals. In Mexico, which lost half its territory over the course of the nineteenth century to the United States, British and American firms negotiated exclusive concessions with Porfirio Diaz, the dictator between 1876 and 1913, who sought to modernize his country to prevent its further humiliation at the hands of the Americans. The British firm of S. Pearson \& Son, for example, was given vast construction contracts for harbors and railroads, and from 1902 onwards also oilfields. ${ }^{7}$ In central America, dictators in Guatemala and elsewhere gave United Fruit and other firms huge concessions to develop banana plantations and related infrastructure. ${ }^{8}$ Throughout Latin America, as well as elsewhere, Western firms negotiated concessions to construct and generate power and light systems - resulting in the electrification of many of the cities of the sub-continent, and most of the developing world, by $1914 .^{9}$

Copyright $\odot 2010$ by Geoffrey Jones

Working papers are in draft form. This working paper is distributed for purposes of comment and discussion only. It may not be reproduced without permission of the copyright holder. Copies of working papers are available from the author. 
The story was repeated on other continents. In Iran, the decaying Qajar dynasty awarded exclusive concessions for banking and oil covering virtually the entire country to the Imperial Bank of Persia and the Anglo-Persian Oil Company, both British-owned and managed despite the use of Persia in their names. ${ }^{10}$ Whether in Central America or in Iran, these concessions were generally free of tax and most other regulations. American or British diplomats, or gunboats, made sure such contracts were enforced.

In terms of their theory of multinational enterprise, in the age of imperialism, Western multinationals experienced little of the alleged "liabilities of foreignness" in most developing countries. Indeed, they could be considered to have captured many of the benefits of being "insiders" in their business systems. ${ }^{11}$ This was not only because of social and cultural connections to colonial regimes, but often more importantly, close connections with other Western firms active in those countries. Western banks, trading companies, shipping companies, plantation and mining ventures not only interacted regularly in host economies, they were also quite frequently linked through equity, non-equity and other links into the same business group. ${ }^{12}$

Multinationals rarely had to adjust or innovate in their strategies in response to competition from locally-owned firms, as there was limited competition. The major exceptions occurred in Japan, where local firms succeeded in challenging Western banks, shipping and trading companies; in India, where a modern cotton textile industry was created by the small Parsee ethnic community; and in some Latin American countries. For example, in Uruguay, Argentina and other countries, there was a growth of locally-owned banks from the late Copyright (C) 2010 by Geoffrey Jones

Working papers are in draft form. This working paper is distributed for purposes of comment and discussion only. It may not be reproduced without permission of the copyright holder. Copies of working papers are available from the author. 
nineteenth century, which successfully challenged Western banks. ${ }^{13}$ More unusual was the success of the Bolivian entrepreneur Simon Patiño in displacing the foreign companies which had initially developed the Bolivian tin industry to become the largest Bolivian producer of tin concentrates before 1914. Subsequently Patiño bought smelters in Britain and Malaya, becoming one of the leading players in the global tin monopoly. ${ }^{14}$

There is limited evidence, then, on the impact of local competition on the strategies of Western firms. One of the most interesting examples occurred in the opium trade between India and China in the nineteenth century. This trade was initially dominated by Scottish merchants, primarily the trading houses of Jardine Matheson and Alexander Dent. Vast fortunes were made. By mid-century, their business was challenged by the Sassoon's and other Baghdadi Jews who had fled from the Ottoman Empire and settled in British India. The Sassoon's were able to rapidly gain market share from the British trading companies selling opium to China. They integrated vertically by becoming bankers to the opium crop dealers in India, enabling them to control production, and they took control of the local opium auctions in India along with other Baghdad Jewish families. Dent’s went bankrupt in 1867, but Jardine Matheson responded to lower cost local competition in a fashion which later other Western multinationals would follow. It withdrew from opium trading, itself under an increasingly cloud of legitimacy as its dangerous medical consequences were realized, and shifted into higher value-added and more respectable activities, including shipping, ports and railroad building, in which held stronger advantages in management and access to finance. ${ }^{15}$

Copyright $@ 2010$ by Geoffrey Jones

Working papers are in draft form. This working paper is distributed for purposes of comment and discussion only. It may not be reproduced without permission of the copyright holder. Copies of working papers are available from the author. 
The major strategic challenges faced by Western multinationals, then, lay more in execution. Finding oil when exploration techniques were primitive; transporting oil from where it was found to where it could be shipped to consumers; building bridges and railroads in inhospitable and physically dangerous terrains; turning malaria-infested tropical lands into banana plantations, were all massive technological, financial and organizational tasks. This is not to claim that most, if any, of the companies involved were heroic, nor that outcomes were socially or environmentally beneficial. However the sheer scale of the logistical challenges helps to explain numerous failed companies. Even the few firms which survived often came close to disaster. Exclusive concessions, excluding firms from taxation, were huge assets - but of little use if no oil was found, or the cost of transporting it was prohibitive. ${ }^{16}$

The multinationals which succeeded in this era, then, needed the technological, and especially the organizational, capabilities required to overcome major logistical challenges. In the case of Pearson in Mexico, for example, the firm transferred best-practice engineering capabilities to its construction projects, proceeding where others failed. In contrast, the firm's oil exploration efforts failed miserably until high quality geologists were hired from the United States. ${ }^{17}$ However organization mattered more than technology. The Singer Sewing Machine Company expanded globally from the 1860s until it held a 90 per cent share of world sewing machine sales by 1914, including in Russia, India and other developing markets. The firm's technology was broadly comparable to other firms, and its success lay in a series of organizational innovations including enabling potential consumers to buy the product using hire

Working papers are in draft form. This working paper is distributed for purposes of comment and discussion only. It may not be reproduced without permission of the copyright holder. Copies of working papers are available from the author. 
purchase, and establishing a direct sales force which enabled it to sell machines, and collect payments. A striking feature of this firm was that these organizational innovations originated in host economies as the firm expanded globally, being subsequently transferred throughout the organization. ${ }^{18}$ This firm depended more on its organizational capabilities than insider advantages, and more developed markets remained the most important part of its business.

Successful organizational innovation to facilitate access to financial resources was also rewarded. The British merchant houses active in Asia, Africa and Latin America functioned as quasi-venture capitalists. They would identify opportunities in resources or other activities, form companies, and then issue most of their capital on either British or colonial equity markets, using their reputations as devices to attract investors who might otherwise have avoided such high-risk investments. The result was the formation of large business groups consisting of core trading companies and many separate companies, joined by equity, debt, contracts and crossdirectorships. These business groups, such as Jardine Matheson, Swire’s, Harrisons \& Crosfield and James Finlay in Asia, and Balfour Williamson and Duncan Fox in Latin America, were successful capital-raising vehicles. They also facilitated the recruitment of high quality expatriate staff, and served to transfer managerial and scientific knowledge between individual companies within a group. ${ }^{19}$

An important managerial capability was to adapt to the quite different legal, market and cultural contexts of developing countries without losing original capabilities. The overall strategy of successful British overseas banks in Asia and elsewhere, for example, showed little Copyright (C) 2010 by Geoffrey Jones

Working papers are in draft form. This working paper is distributed for purposes of comment and discussion only. It may not be reproduced without permission of the copyright holder. Copies of working papers are available from the author. 
innovation. They focused on trade finance and foreign exchange, and as in Britain, short-term lending was the norm, and equity stakes in industrial or agricultural ventures were never taken voluntarily. The execution of this strategy, however, was more radical. While in Britain, banks would always lend on the basis of security, usually property, in many developing countries this was not an option, sometimes, as in Iran, because of legal restrictions on the foreign ownership of property. British banks ended up, as a result, lending against share certificates, commodities, and even a person's reputation. They also engaged in extensive lending and borrowing with indigenous bankers, whether compradors in China, shroffs in Sri Lanka, or sarrafs in Iran. ${ }^{20}$ Again, however, there was a need for organizational capabilities to match the external environment. The Oriental Bank, the largest overseas bank in the second half of the century, failed in 1884 after opening branches in several continents, rather than following the norm of much greater geographical concentration. This gave it insufficient knowledge of local business conditions, leaving it exposed to bad debts. ${ }^{21}$

The multinationals which succeeded most in developing countries in the first global economy, then, combined contact capabilities with colonial regimes and other Western business networks with organizational capabilities, especially the ability to respond flexibly but effectively to often more unpredictable and challenging operating conditions than in their home countries. The logistical challenges of doing business developing countries meant that successful firms cannot be regarded as mere free riders on Western imperialism.

Copyright $\odot 2010$ by Geoffrey Jones

Working papers are in draft form. This working paper is distributed for purposes of comment and discussion only. It may not be reproduced without permission of the copyright holder. Copies of working papers are available from the author. 


\section{Multinational Strategies in Developing Countries in the Era of De-globalization, c1929-c1978}

The main drivers of the de-globalization which characterized much of the twentieth century are well-understood. The Great Depression, and its aftermath in the form of exchange controls and tariff barriers, dramatically reduced international trade, and virtually halted the growth of multinational investment. The spread of nationalistic, anti-foreign governments, sharply raised political risks during the 1930s, further prompting firms to form cartels rather than risk investing in foreign countries, or employ other non-equity forms. The growth of tariffs in interwar Latin America, for example, led US multinationals to subcontract production of their brands to local manufacturers. ${ }^{22}$ World War 2 devastated Europe and much of Asia, and eventually led to the expropriation of German and Japanese FDI.

After 1945, multinationals did not need a strategy for many emerging markets - because they were excluded from doing business in them. The Communist Revolution in Russia in 1917 had resulted in the expropriation of a large amount of Western FDI, as Russia had been one of the world's largest host economies. The spread of Communism to China and eastern Europe after World War 2 shut off further large parts of the globe to capitalism. The dismantling of Western colonial empires, the spread of government restrictions on foreign firms in most of postcolonial Asia and Africa, and the widespread expropriation of foreign ownership of natural resources during the 1970s, further decimated Western multinational investment in developing countries. In 1929 India, China and many other developing countries where among the top twenty hosts for FDI. By 1980 levels of FDI in those countries was zero, or close to zero, and almost two-thirds Copyright (C) 2010 by Geoffrey Jones

Working papers are in draft form. This working paper is distributed for purposes of comment and discussion only. It may not be reproduced without permission of the copyright holder. Copies of working papers are available from the author. 
of world FDI was located in Western Europe and North America. By that date, the integration of worldwide capital, commodity and labor markets remained much less than sixty years previously.

Paradoxically, the previous strategies of many Western multinationals had contributed significantly to the growth of restrictive, anti-foreign policies which now excluded them from many developing countries. The close links between companies, colonial regimes and oppressive dictators served to undermine the legitimacy of global capitalism in the eyes of many people. There seemed to be few benefits to countries and their peoples of foreign multinationals, and huge downsides. Many of natural resource investments had been highly enclavist. Most minerals and agricultural commodities, for example, had been exported with only the minimum of processing. This meant that most value was added to products after they left producer countries. Foreign firms had been large employers of labor. US mining and smelting properties in Mexico alone are estimated to have employed more than 500,000 in 1915, but here and elsewhere expatriates held all the skilled and managerial posts. ${ }^{23}$ It was a similar story with the Frenchcontrolled Suez Company, which built and operated the Suez Canal in Egypt between 1854 and its nationalization in 1956. The Canal had a major stimulus on the Egyptian economy, but until 1936 the Egyptian staff was almost exclusively unskilled workers. ${ }^{24}$

There were other downsides too. As concern for the environment rose in the West, especially from the 1960s, the environmental havoc wreaked by many multinationals in developing countries in the past, whether through banana plantations, mining, or logging Copyright (C) 2010 by Geoffrey Jones

Working papers are in draft form. This working paper is distributed for purposes of comment and discussion only. It may not be reproduced without permission of the copyright holder. Copies of working papers are available from the author. 
operations, became evident. ${ }^{25}$ This damage persisted as some firms may have transferred more hazardous operations to developing countries, or operated plants with standards which would not have been permitted in the developed world. These risks were highlighted when the plant of Union Carbide, a leading US chemicals company, leaked toxic gas on the town of Bhopal in 1984, immediately killing almost 4,000 people mostly in the slum next to the plant, and inflicting long-term health damage on many thousands more local inhabitants. ${ }^{26}$ The aggregate evidence for a crude "pollution haven" hypothesis is, however, weak, though this does not mean that multinationals did not take decisions on environmental strategies which did not have negative outcomes. $^{27}$

Given that the major challenges faced by Western multinational firms were political and regulatory, responses to political risk rose to the forefront of corporate strategies. The end of imperialism, and the adoption of more assertive government policies in many developing markets, did not initially prompt multinationals to divest their investments. Indeed, there was initially considerable optimism among Western firms after 1950 about the economic prospects of Latin American, West Africa and Asian countries. This prompted new Western multinational investment, as firms were anxious to get a share of what looked fantastic growth opportunities. German multinationals, for example, invested heavily in a number of developing countries, especially Brazil, but also Argentina, India and Iran. By 196138 per cent of all German FDI was in developing countries. But as political and economic problems mounted, German firms shifted

Working papers are in draft form. This working paper is distributed for purposes of comment and discussion only. It may not be reproduced without permission of the copyright holder. Copies of working papers are available from the author. 
their attention to Europe. By 1971 only 20 per cent of German FDI was in developing countries. $^{28}$

During the 1960s and 1970s there was a general exodus from developing countries. British overseas banks, such as Standard Chartered and Lloyds Bank International, turned their backs on their large historical franchises in Asia, Africa and Latin America, embarking on acquisitions in the United States and in Britain, frequently with disastrous outcomes. ${ }^{29}$ As taxes and regulations grew in India, British firms and shareholders sold their interests and investments to Indian-owned business groups such as the Tata's and Birlas. ${ }^{30}$ Most major US firms, including IBM, also fled from India in response to government insistence on majority ownership of their affiliates. In Malaysia, British companies remained prominent during the 1960s, in part because the new ethnic Malay government was concerned to keep a check on the minority, ethnic Chinese business sector. However the strategies of the British firms were molded by the postcolonial government, and as frustration with the government mounted, and concerns about the future, the long-established merchant houses began to seek opportunities outside the country. ${ }^{31}$ In the late 1970s and early 1980s, steps were taken to reduce the role of British and other Western firms in the plantation and mining sector even in Malaysia. In 1981 the Malaysian government, using adroit moves on the London Stock Exchange, secured control over the largest British rubber and oil palm business in Malaysia, the Guthrie Corporation. ${ }^{32}$

As tensions mounted between governments and firms, sometimes multinationals sought the assistance of their home governments to resist expropriation. In the early 1950s, United Fruit Copyright $\odot 2010$ by Geoffrey Jones

Working papers are in draft form. This working paper is distributed for purposes of comment and discussion only. It may not be reproduced without permission of the copyright holder. Copies of working papers are available from the author. 
lobbied extensively, making expert use of public relations consultants, to secure US intervention against the democratically elected government of President Jacobo Arbenz in Guatelama, after he had sought to expropriate the millions of unused land which they held as part of their banana empire. Arbenz was overthrown by a CIA-orchestrated coup in 1954, and a military dictatorship installed..$^{33}$ The nationalization of the Anglo-Iranian Oil Company's oil concession in Iran in 1951 was also eventually met by a British and American orchestrated coup which overthrew the government in 1953, although in this instance Anglo-Iranian, and its stake in the Iranian oil industry, was marginalized during the years leading up to the coup. ${ }^{34}$ The nationalization of the Suez Canal Company prompted an unsuccessful British and French invasion of Egypt, alongside their Israeli allies. By the 1970s companies were rarely able to topple governments, even when they wanted to, although the role of International Telephone and Telegraph and the CIA in overthrowing the Chilean government of Salvador Allende in 1973 remains a classic episode in multinational-government relations.

Most multinationals, if they did not divest, strove to adjust their strategies to postcolonial realities rather than thwart them. In the West Indies, the large British banks began recruiting black staff, and decentralized decision-making to the region as independence approached during the 1950s. ${ }^{35}$ In British colonial Africa, there was a widening rift between British firms and colonial governments as states such as Nigeria and Ghana approached independence. ${ }^{36}$ The firms shifted their political networks to the emerging elites of these countries. British banks, traders and manufacturing companies used their advertising to remold their corporate images as agents

Copyright (C) 2010 by Geoffrey Jones

Working papers are in draft form. This working paper is distributed for purposes of comment and discussion only. It may not be reproduced without permission of the copyright holder. Copies of working papers are available from the author. 
of modernity and economic development in West Africa. This strategy met with considerable success, at least until the 1970s when the spread of dependency and socialist ideologies seriously challenged the legitimacy of capitalist enterprise. ${ }^{37}$

There were other strategies also to align the interests of multinationals with changing political realities. Among the most important was the localization of staff. The Anglo-Dutch consumer products company Unilever began experimenting with appointing nationals to managerial positions in India and Ghana in the 1930s. The localization of its management in developing countries intensified thereafter, driven in part by a desire to reduce costs. While in 1940 virtually all of Unilever's managers in Hindustan Lever, its Indian affiliate, were expatriates; by 1950 it only had 50 expatriates, and by 1966 there were only 6 expatriates out of a total of 360 managers in what had become one of India's biggest companies. Encouraged by the government, Unilever also sold 10 per cent of the equity of Hindustan Lever in 1956, and appointed an Indian national as chairman in 1961. Although Unilever disliked selling equity in its affiliates, it pursued localization of management vigorously. By 1966, of the 2,965 Unilever managers in developing countries, only 8 per cent were expatriates. ${ }^{38}$

The localization of staff is significant in explaining the scale and scope of Unilever's business in developing countries during these decades, which was strikingly large compared to its major US competitor Procter \& Gamble, which seldom ventured into developing countries before the late 1980s, primarily because of fears about political risks and hyper-inflation. ${ }^{39}$ It provides an important part of the explanation how Unilever was able to retain control over large Copyright (C) 2010 by Geoffrey Jones

Working papers are in draft form. This working paper is distributed for purposes of comment and discussion only. It may not be reproduced without permission of the copyright holder. Copies of working papers are available from the author. 
businesses in countries such as India and Turkey where FDI as a whole dropped to low levels as a result of government exchange and price controls, as well as demands for majority equity participation in local subsidiaries. The early localization of senior management was critical in providing voice, contacts and legitimacy in such countries, embedding the firm in local business and political systems. Unilever identified, and promoted to the most senior positions, some of the best business leaders of their generation in these and other developing countries. This meant not only that Unilever's businesses were managed by good people, but also that it was able to function as a quasi-insider within governmental and business networks in countries.

In Unilever's case, there were other considerations also. It was already selling and manufacturing in India in the interwar years, and entered Turkey in 1950. As Import Substitution Industrialization regimes were adopted, Unilever was well-situated inside protected domestic markets, even though it had to contend with price and capacity controls, dividend limitations and other government regulations. Unilever was able to transfer brands, technologies and marketing methods from its businesses in developing markets, and exploit them behind tariff walls. Unilever's decentralized management structure permitted flexibility in adjusting to the different environments in these countries. In countries such as India and Turkey, the company made margarine from sunflower oil and toilet soap from palm oil. It invested in tomato puree, jasmine plantations and chemicals. It exported shoes to met government-imposed export quotas. It engaged in rural development in India, and built its own power plants to run factories. This flexibility helped the local managers of the company, especially during the fraught 1970 s, to

Working papers are in draft form. This working paper is distributed for purposes of comment and discussion only. It may not be reproduced without permission of the copyright holder. Copies of working papers are available from the author. 
engage in prolonged negotiations to delay government plans for local subsidiaries to become locally-owned. In both countries, as a result, Unilever was able to retain majority control until the early 1980s, when pressures for localization abated.

Unilever's strategy in developing countries rested on patience regarding rates of return. Unilever took a long-term view that sooner or later as incomes rose, people in every country would want to consume the company's products. It accepted low dividend remittances for years, or decades, from both India and Turkish businesses, as well as many countries in Africa, both to build up businesses, and to wait for better times. It made large investments in plant and equipment - often at the expense of short-term remittances for dividends to its shareholders - in order to build sustainable businesses. Only a firm of its size and financial strength, as well as willingness to put managerial imperatives ahead of shareholder interests, could take such decisions. $^{40}$

Learning to negotiate with the governments of developing markets was the key to corporate success in this era. The case of the Brazilian automobile industry illustrates its importance. During the 1950s the government of President Juscelino Kubitschek implemented strategies to encourage foreign firms to build an automobile assembly industry in his country. The strategy involved both foreign exchange and tax subsidies, alongside the progressive closure of the market to imported finished vehicles. Despite multiple pleas from the government, Ford, which assembled vehicles from kits and had dominated the market, refused to invest in automobile assembly, as did its major US rival, General Motors. Instead Germany's

Working papers are in draft form. This working paper is distributed for purposes of comment and discussion only. It may not be reproduced without permission of the copyright holder. Copies of working papers are available from the author. 
Volkswagen, which had no production beyond its home country before 1956, successfully entered vehicle production. By the mid-1960s, Volkswagen had captured over 40 per cent of the expanding Brazilian market, while former market leader Ford had been reduced to 6 per cent, and General Motors to 7 per cent. ${ }^{41}$ In other countries, government import controls and restrictions on foreign ownership forced multinational car companies which wanted to sell in them to make licensing and other agreements with locally-owned or controlled firms. In Turkey, for example, Fiat, Renault and Ford reached such agreements with large Turkish business groups. ${ }^{42}$

Multinationals in the resource sector had less scope to negotiate with governments. From the late 1960s governments in most developing markets moved to take over foreign ownership of the natural resources in their countries. Often this was done by outright nationalization, which left companies little to negotiate about except, if they fortunate, compensation terms. In more pro-Western countries, such as Malaysia, state-owned companies were used as vehicles to buy the foreign companies which owned the country's vast rubber and oil palm plantations, with domicile then being transferred back to Malaysia and the management localized. ${ }^{43}$ Whilst local ownership over natural resources became a matter of principle for many governments, control was another matter. In the case of plantations, Western companies often negotiated long-term purchasing and technical contracts with local producers, leaving them with the most valuable parts of the commodity value chain - transport and distribution - whilst relieving them of the

Working papers are in draft form. This working paper is distributed for purposes of comment and discussion only. It may not be reproduced without permission of the copyright holder. Copies of working papers are available from the author. 
embarrassment of employing and managing tens of thousands of impoverished plantation workers. $^{44}$

The limited scope for negotiation was especially evident in the petroleum sector. The large Western oil companies, which counted amongst the largest capitalist enterprises on the planet, found themselves especially exposed to growing political risk in the Middle East and Latin America. Although the attempt to nationalize the oil industry in Iran in 1951 was thwarted, there was growing pressure from host countries for more control over their own resources, and for more participation in the benefits of oil, as energy consumption boomed during the postwar era of economic miracles in Europe and Japan, and as the United States was transformed from being an oil exporter to an oil importer. During the late 1960s Venezuela, Saudi Arabia, Iran, Iraq, Libya and others formed the Organization of Petroleum Exporting Countries. In 1968 OPEC issued a statement declaring the inalienable right of oil producers to exercise permanent sovereignty over their natural resources. In 1970 Libya began a process of countries demanding greater shares of the profits from their oil; by 1972 countries were demanding shared participation; and after the Arab-Israeli War of 1973, governments in the Arab world began nationalizing their industries. Venezuela nationalized its large oil industry, in which Shell was a major investor, in 1975.

These events undermined the business model based on vertical integration which was central to how the oil industry had operated since the late nineteenth century. The momentum behind the new policies left the oil companies little negotiating flexibility to stop them. Instead Copyright $\odot 2010$ by Geoffrey Jones

Working papers are in draft form. This working paper is distributed for purposes of comment and discussion only. It may not be reproduced without permission of the copyright holder. Copies of working papers are available from the author. 
there was innovation in new strategic directions. The most successful new strategy involved switching their exploration efforts towards the North Sea and Alaska. Both terrains posed challenging geological and logistical conditions, making exploration a high-risk endeavor. In the end BP, which was heavily dependent on Middle Eastern oil and faced a threat to its existence, secured its future by making major discoveries, just in time, in Prudhoe Bay, Alaska and the Forties, North Sea, in 1969-70. Shell also made major exploration efforts offshore, and was especially successful in the North Sea. Two other strategies were pursued. First, as developing countries established their own oil companies on the basis of the nationalized assets, Shell in particular, but also the other companies, sought to enhance their technical skills, and become providers of technical services to these companies. This proved quite successful also, although the Kuwait Oil Company and other national oil companies quickly developed managerial and technological competences. A final strategic innovation, involving large-scale diversification and acquisitions into other minerals, chemicals, nuclear energy, and much more, proved hugely unsuccessful for all companies. ${ }^{45}$

In the first era of globalization, Western multinationals had paid limited attention to the consumer markets of developing countries, as they were too poor to buy anything but basic items. After World War 2, this strategy began to slowly change, but there were major issues of what to sell, and how to sell it. In consumer products, firms initially transferred products from developed countries to developing markets as their incomes rose. There was little product innovation as such, therefore, although sometimes brand images were changed, and sometimes

Working papers are in draft form. This working paper is distributed for purposes of comment and discussion only. It may not be reproduced without permission of the copyright holder. Copies of working papers are available from the author. 
consumers themselves found new uses for products. Because little attempt was made before the 1980s to reformulate shampoos for none-white ethnicities, for example, Vaseline petroleum jelly, created in mid-nineteenth century America and used as soothing skin cream, became widely used in postwar Africa as a hair product.

The direct transfer of Western consumer products to developing countries was sometimes highly problematic. The adverse consequences of the marketing of baby food by Nestlé became a cause célèbre, as it emerged that mothers regularly mixed the formula with polluted water, or else effectively starved their babies as they could not use sufficient of the product. ${ }^{46} \mathrm{~A}$ deleterious was the spread of cigarette consumption. From the early twentieth century Western tobacco companies had played an inglorious role in using their marketing and distribution capabilities to grow cigarette consumption in Asian and other developing countries. ${ }^{47}$ During the second half of the century, as health concerns and consequent regulation mounted in developed countries, cigarette multinationals expanded their businesses in developing countries. ${ }^{48}$

In many other cases, the attempt to transfer Western consumer products to developing country markets was just commercially unsuccessful. During the 1960s, for example, Unilever tried to sell its margarine in Thailand, only to discover that in countries which ate rice rather than bread, the market was strictly limited. Similarly, Unilever's early attempts to sell ice cream in countries where electricity supplies were unreliable were not successful. Nor were attempts to sell branded convenience foods to countries where the urban middle class ate out cheaply on street stalls or in restaurants, while the rest of the population was too poor to buy branded Copyright $@ 2010$ by Geoffrey Jones

Working papers are in draft form. This working paper is distributed for purposes of comment and discussion only. It may not be reproduced without permission of the copyright holder. Copies of working papers are available from the author. 
products. ${ }^{49}$ It proved somewhat easier to sell some beverages to developing countries. Nestlé's Nescafe instant coffee, invented in 1938, proved to be remarkably global food product. Both Heineken lager and Guinness stout were incredibly successful in Africa from the 1950s. Nigeria became, and has remained, one of Guinness's large markets, thanks in part to a clever marketing gambit which advertized the brand as a means to increase male sexual potency. Coca Cola was also successful in developing markets, although the image of the brands was so closely associated with the United States that it faced political problems in several countries. It was expelled from many Arab countries in 1966 after opening a franchise in Israel, and banned from India between 1977 and 1992, after refusing to divulge its secret formula. ${ }^{50}$

It was only in the 1970s that Western firms began to invest in product innovation designed to deliver products especially for developing country markets. Unilever's large Indian affiliate, Hindustan Lever, which had created its own research facilities in the 1950s, was among the pioneers. It began selling its own distinctly Indian shampoo and toothpaste brands, as well as brands from Unilever's global portfolio. More interesting, was the creation of Fair \& Lovely skin-lightening cream in 1978. This was cream designed to appeal to a traditional regard for fairer skin in India. The origins of such preferences lay deep in Indian history, which some traced back to the origins of the caste system two and a half thousand years ago, when fair-skinned foreigners established a class system with the indigenous darker-skinned local population at the bottom. Much later, the era of British rule introduced a new set of rulers with lighter skins. Hindustan Lever now applied its scientific and branding capabilities to translate such cultural

Copyright $@ 2010$ by Geoffrey Jones

Working papers are in draft form. This working paper is distributed for purposes of comment and discussion only. It may not be reproduced without permission of the copyright holder. Copies of working papers are available from the author. 
preferences into a highly successful brand, which became the best-selling skin care brand in India. Fair \& Lovely was based on a patented formulation containing an active ingredient which controlled the dispersion of melanin in the skin. The brand's advertising promised greater fairness within six weeks of using the product, and from the beginning the brand emphasized the improved marriage prospects of fair-skinned women. Considerable use was made of endorsement by celebrities from the huge Indian cinema industry known as Bollywood, whose leading actors and actresses were overwhelmingly fair-skinned. ${ }^{51}$

There were also innovations in how to market consumer products to developing countries. In the beauty industry, the strategies of Avon, the American direct seller, were particularly important. Although founded in the late nineteenth century, Avon only invested in Canada before 1954. It then started to expand to Latin America, followed later by Asia and, after 1990, Russia and other eastern European transition economies. Avon's direct selling model was an enormously important innovation for developing countries, many of which lacked sophisticated distribution channels to sell cosmetics and toiletries, and other consumer products, especially outside major towns. The recruitment of thousands of direct sellers opened up a new distribution channel which enabled Avon over time to access social and familial networks which otherwise would have been extremely difficult to reach. ${ }^{52}$

Recruiting a direct sales network from scratch in a developing country was a lengthy process, as was building a market for modern beauty products. As Avon expanded its business into Latin America, it devoted considerable resources to educating consumers in the use of their Copyright (C) 2010 by Geoffrey Jones

Working papers are in draft form. This working paper is distributed for purposes of comment and discussion only. It may not be reproduced without permission of the copyright holder. Copies of working papers are available from the author. 
products. Avon's entry into new markets followed an established pattern. It began with acquainting representatives and customers with the Avon line. Avon sought to provide new representatives with the "best possible line of products at an attractive price" and, thus, an attractive earning opportunity. Products were transferred from the United States, but with local variation to suit markets, and fewer products were made available than in the American market. As markets began to become saturated - which Avon was defined as coverage of one representative per 1000 people - new products and packaging became important to give representatives the means to open the way for re-orders. ${ }^{53}$

This standard pattern needed to be modified to local circumstances in each market. For example, when Avon sought to open in Mexico in 1958, the local legislation required the company to equip a factory and recruit and train its staff before a single representative could be appointed. It also found that local knowledge of how to use or even buy cosmetics was weaker than in Venezeula, requiring a major educational effort. As an Avon executive recalled five years later, "many women do not know how to use or even buy various cosmetics. In some cases they have seen them advertised or heard of them, but would not buy or use them for fear of showing their lack of knowledge”. ${ }^{4}$ The sheer size of Brazil, where Avon also opened in 1958, and its poor domestic transportation presented severe logistical challenges to making deliveries and receiving payments. The company responded by setting up its own carrier system. Brazil also obliged Avon to create a new accounting system in response to inflation rates which by the early 1960s had reached 5 per cent a month. ${ }^{55}$

Copyright $@ 2010$ by Geoffrey Jones

Working papers are in draft form. This working paper is distributed for purposes of comment and discussion only. It may not be reproduced without permission of the copyright holder. Copies of working papers are available from the author. 
Avon's direct selling model was successful in many countries. By the early 1960s the firm had secured strong market positions in many Latin American countries, including Venezuela, where it held 50 per cent of the cosmetics market, and it began local manufacturing in $1960 .^{56}$ The major setback came in Cuba, where a business opened in 1955 had grown so fast that a factory was opened a mere three years later, only to have the entire business was then nationalized after Fidel Castro took power in $1959 .^{57}$

In most countries, if Western multinationals stayed, or were allowed to stay, they faced limited competition from local firms. Indeed, the government policies of this era were often as destructive of local capitalist enterprise as they were of foreign investment. In 1952 Bolivia, for example, became the first country to take over its tin industry. Although the Patiño group remained important in the marketing and smelting of tin, it was fragmented because of the loss of ownership of the mines. The same phenomenon was seen in Africa. Egypt had a highly developed private sector in an African context. Yet, by the 1960s, its large-scale private sector had been entirely dismantled by government policies. Nigeria’s business communities, which had once appeared as dynamic forces, lost energy as they became deeply engaged in the ethnic and regional rivalry that became a feature of the country.

As governments imposed extensive regulatory regimes, local entrepreneurs in developing markets grew their businesses more by using “contacts” rather than building technological and organizational capabilities. This did not necessarily prevent the creation of large firms, although it usually provided a weak foundation for competitiveness against Western firms, apart from Copyright $@ 2010$ by Geoffrey Jones

Working papers are in draft form. This working paper is distributed for purposes of comment and discussion only. It may not be reproduced without permission of the copyright holder. Copies of working papers are available from the author. 
their close connections to their government. An example was the CP Group, which became the largest Thai-owned multinational. The firm became a major animal feeds manufacturer after the Second World War. In 1971 a joint venture with a leading U.S. poultry breeding firm, became the basis for the creation of a modern integrated chicken business in Thailand. Further diversification followed into real estate and retailing, often through joint ventures with Western firms. However the firm's major growth in telecommunications was achieved through CP's close contacts with leading politicians, while its rapid growth in China after 1979 - where it became one of the largest foreign investors - was based on ethnic ties. ${ }^{58}$

India provided one case where local firms were able to slowly build organizational capabilities, despite the inefficiency and corruption of the country's quasi-socialist planning system. Indeed, the era laid the basis for India's subsequent success in information technology. During the 1960s and 1970s a handful of locally-owned firms were established to develop and run applications software for Indian companies and research institutions that had brought or leased mainframes from IBM and other US companies. Tata, which was India’s largest business group, established the first of these firms, Tata Consulting Services in 1968. In 1977 when the Indian government tightened the laws on foreign ownership of firms in the country, IBM and other US firms divested, opening new opportunities for the Tata venture, and for subsequent start-ups such as Infosys. Although the productively and effectiveness of Indian firms was highly constrained by planning controls and other bureaucratic obstacles, once policies were changed

Working papers are in draft form. This working paper is distributed for purposes of comment and discussion only. It may not be reproduced without permission of the copyright holder. Copies of working papers are available from the author. 
after 1991 they had the scale to expand rapidly, becoming potential challengers to Western and Japanese multinationals.

One early challenger to multinationals came in detergents, where Nirma Industries challenged the long-established hold on the Indian market by Unilever by introducing a gamechanging low-priced detergent. The Indian fabrics market until then had been dominated by hard soap, and Unilever's expensive, premium powder brand Surf was decimated after 1975 when Nirma launched a powder at parity with hard soaps, but with much better washing powder, providing a new value for money concept. Having begun with such low price products, Nirma moved up-market with products which directly competed with Unilever's customer base and took market share from them. It was only after a significant delay that Hindustan Lever was able to respond with low cost but quality product, although it turned out that this traumatic episode exercised a long-term impact on Unilever's strategy in developing markets. ${ }^{59}$

The multinationals which succeeded best in developing markets in this environment tended to have decentralized management systems which were capable of turbulent economic and financial environments, and dealing with high levels of intervention by governments.

\section{Multinational Strategies in Developing Markets in the Second Global Economy, c.1978 -}

There is no consensus when the contemporary era of globalization began. A good case could be made for dating it to the 1960s, especially because of the appearance and growth of

Working papers are in draft form. This working paper is distributed for purposes of comment and discussion only. It may not be reproduced without permission of the copyright holder. Copies of working papers are available from the author. 
global financial markets, which eventually undermined governmental restrictions on capital movements. However, insofar as political factors had drove de-globalization, it is more appropriate to take China's adoption of market-oriented policies in 1978 as chronological starting point for the new global economy. The subsequent growth of the Chinese economy set off a chain of pressures and events which encouraged developing countries, especially India to 1991, to follow suit. The advent to power of the right-wing, free-market governments of Margaret Thatcher and Ronald Reagan in Britain and the United States respectively, in 1979 and 1980, and the collapse of the Soviet Union and the Communist states of eastern Europe at the end of the 1980s, fuelled the momentum which drove down barriers to global capitalism and foreign investment. It remains unclear whether this second era of globalization has begun to unravel as a result of the global financial crisis beginning in 2008.

The new political environment transformed the opportunities for Western multinationals in developing countries, at least until the new century. Restrictions on foreign ownership, pressures to make joint ventures with local firms, trade barriers and exchange controls, melted away or were greatly reduced. Deregulation and privatization opened up sectors such as telecommunications which had long been closed to foreign companies. Indeed, practically every government on the planet offered incentives for multinationals to invest in them. It was striking, however, that although FDI in developing countries increased rapidly, it showed no signs of recovering to the relative importance it had once held in the first global economy. (See Table 1) Indeed, multinational investment was heavily clustered in a handful of countries, led by China,

Copyright (C) 2010 by Geoffrey Jones

Working papers are in draft form. This working paper is distributed for purposes of comment and discussion only. It may not be reproduced without permission of the copyright holder. Copies of working papers are available from the author. 
Mexico, Brazil and Argentina, and city states such as Hong Kong and Singapore, whilst India, Russia, and most of Africa and Latin America received little investment, despite large-scale liberalization of regulation.

The nature of political risk now assumed new, and often more subtle, forms. There was no reversion to the era when Western firms, supported by their home governments, could dictate their terms to developing countries. Despite numerous bi-lateral agreements and the WTO, there was still no generally accepted international law which protected foreign investments from expropriation. Nor was the protection of intellectual property secured by international law. The governments of the major developing economies could dictate terms to multinationals. Foreign multinationals in China operated at the discretion of the Chinese government, and were most unwise to pursue policies which ran counter to its desires. Lacking an autonomous legal system, companies which sold consumer products depended on the goodwill of the Chinese authorities to take action against counterfeiters. The Chinese government expected firms such as Cisco, which sold internet routers, to facilitate its monitoring and control over the internet. In such a strategic industry as internet routers, the position of foreign firms such as Cisco was particularly sensitive. Control of the Web was a major strategic concern of the ruling Communist Party, whilst China also had ambitions to set its own technical standards in high-technology industries. There was evident political support behind locally-owned Huawei Technologies, established in 1988, which grew rapidly after it began to make telecom equipment in the mid-1990s, becoming a leading 
supplier of digital switches and routers in China, and by had secured 3 per cent of the world market for internet routers by $2008 .^{60}$

Elsewhere, the new century brought some signs of a reversion to older forms of political risk in some host countries. The multinational oil companies which had invested in Russia found themselves forced to reduce their shareholdings in concessions. In 2005 Shell was forced by Russia to halve its stake in its huge Sakhalin-2 project in Siberia from 50 per cent to 27.5 per cent, while Mitsui and Mitsubishi also had their shareholdings reduced to 12.5 per cent and 10 per cent respectively. BP had a joint venture company in Russia, TNK-BP, and ran into a dispute with the four Russian oligarchs it signed the joint venture deal with in 2003. The joint venture was huge, and represented one-quarter of BP's total reserves, but with government support the British management and influence was progressively reduced during 2008 and 2009. In Venezuela, the Chavez government began nationalizing industries after 2007, with multinationals from many countries being affected in the oil, communications, power and cement industries. In many Latin American countries, and some elsewhere, some anti-foreign restrictions became evident, as they were in developed economies, especially the United States. It remained unclear whether these were temporary aberrations from the trend towards liberalization in emerging and transition economies, or harbingers of a new wave of resistance to foreign ownership.

Multinationals also encountered a new form of political risk - legal action in developed countries, notably the United States, for alleged human rights abuses in developing countries. Copyright $\odot 2010$ by Geoffrey Jones

Working papers are in draft form. This working paper is distributed for purposes of comment and discussion only. It may not be reproduced without permission of the copyright holder. Copies of working papers are available from the author. 
Although there remained no international law regarding the human rights obligations of multinationals, companies found themselves increasingly vulnerable to litigation under the obscure Alien Tort Claims Act (ATCA) of 1789. This 33-word act of the newly-established United States specified that "The district courts shall have original jurisdiction of any civil action by an alien for a tort (civil wrong) only, committed in violation of the law of nations or a treaty of the United States.” The Act lay dormant for almost two hundred years, until in 1979 it was used against a Paraguayan police inspector living in the United States, was accused of torturing and killing the son of a Paraguayan dissident in Paraguay. The victim's relatives won a $\$ 10$ million judgment, which was never paid. During the 1990s, the ATCA was used to bring claims of torture, murder, and human rights violations against government officials including Ferdinand Marcos of the Philippines and Radovan Karadzic of Serbia.

However, for multinationals, the most significant feature of ACTA was that, in addition individuals, companies could be sued in US courts for internationally recognized human rights violations anywhere in the world. In the early 1990s, the ATCA was used to win a \$1.25 billion settlement against Swiss, German, and Austrian firms that used forced or slave labor during the Nazi regime. Subsequently it began to be used against multinationals for alleged abuses in developing countries. In 1996 Burmese citizens filed a class-action suit against the US-owned oil company Unocal for abuses committed by the Burmese military against citizens during the construction of a pipeline. In 1999 a class-action suit on behalf of 11 Indonesian villagers against Exxon Mobil Corporation. The suit alleged that Indonesian soldiers paid by Exxon to protect a

Copyright $@ 2010$ by Geoffrey Jones

Working papers are in draft form. This working paper is distributed for purposes of comment and discussion only. It may not be reproduced without permission of the copyright holder. Copies of working papers are available from the author. 
gas-production facility turned on local citizens, committing murder, rape, torture, and kidnapping. In 2003 a group of large multinationals, including IBM and Shell, were sued for their role in supporting the apartheid regime in South Africa. Although it proved difficult to win ACTA cases, the legal costs and bad publicity generated by the cases became a major issue for companies. In 2004 Unocal settled the lawsuit brought by Myanmar villagers. In 2009 Shell agreed to pay \$15.5 million to settle an ACTA lawsuit which alleged that it was complicit in the executions of the activist Ken Saro-Wiwa and other civilians by a military regime in Nigeria in 1995. Saro-Wiwa had campaigned against the alleged environmental damage caused to the region of Ogoniland by Shell drilling. ${ }^{61}$ Given the political and security circumstances in many developing countries, especially in Africa, ACTA obliged multinationals to give increased attention to human rights and environmental strategies, and to resolve complex issues related to different legal and ethical standards between some developed and some developing countries.

There were also new complexities arising from the changing nature of markets. On the one hand, globalization appeared to be working towards a further homogenization of markets worldwide. Ohmae’s “borderless world” and Friedman’s “flat world” were among the popular descriptions of such homogenization trends. ${ }^{62}$ The evidence of flattening seemed visible in everything from the worldwide spread of English to the presence of McDonald's hamburger stores in 120 countries. The growing populations of developing countries, especially their urban middle classes with rising incomes, resulted in fast-growing markets for industries extending

Working papers are in draft form. This working paper is distributed for purposes of comment and discussion only. It may not be reproduced without permission of the copyright holder. Copies of working papers are available from the author. 
from pharmaceuticals to automobiles. The contrast with the ageing populations of many Western countries and Japan was stark.

On the other hand, there were also other processes at work also. The globalization of the ubiquitous hamburger helped stimulate, around the world, a local, cultural, ethnic, religious reaction, which was termed "tribalization” by the political theorist Benjamin Barber. ${ }^{63}$ As global markets spread, existing consumer and social groupings began to fragment as local cultures asserted themselves with greater confidence.

To revert to the example of the beauty industry, the result was a new set of marketing opportunities and challenges for multinationals. The opportunities in developing countries were enormous. In the 1980s the United States, Western Europe and Japan were the dominant markets for the industry. In contrast, China's consumption of beauty products other than toiletries was close to zero; the Soviet Union was virtually closed to foreign firms; and India was an inwardlooking planned economy with discretionary spending on cosmetics limited to rich urban elites. Brazil, historically a bigger spender on beauty products, was experiencing a decade of "lost growth” after the world debt crisis with disastrously high inflation rates. By 2009 there had been remarkable changes. There were limited growth prospects in the mature, and ageing, markets of the West and Japan. In contrast, Brazil, China, Russia and India had become the world's third, fourth, eighth and fourteenth largest beauty markets. Collectively these four countries now accounted for one-fifth of the world market of $\$ 330$ billion. As these countries had liberalized and begun to experience rapid economic growth, their urban middle classes began spending Copyright (C) 2010 by Geoffrey Jones

Working papers are in draft form. This working paper is distributed for purposes of comment and discussion only. It may not be reproduced without permission of the copyright holder. Copies of working papers are available from the author. 
rising incomes on beauty products. In China and Russia, in particular, the industry's products provided symbols of individualism and aspiration which had been denied to consumers by past regimes.

The culturally-specific beauty industry was a particularly good example of the tensions between flatness and tribalization in the second global economy. The spread of mega-brands such as Procter \& Gamble’s Pantene shampoo and L’Oréal Paris skin cream and cosmetics to this new generation of consumers in emerging and transition economies; the globalization of celebrity culture; and the diffusion of the aspirational appeal of New York and Paris, and in Asia of Tokyo, provided strong evidence of homogenization. Yet there was also a resurgence of pride in local beauty identities throughout the developing world. This obliged firms to innovate in ways to make global brands seem locally relevant.

These conflicting trends were evident in the booming China beauty market. As the market began to grow during the 1980s, local brands had been perceived as poor quality and lacking aspirational qualities. As a result, Japanese and Western brands rapidly gained market share, even if product formulations were changed, and if firms responded to local preferences for skin-whitening products. By the 1990s there was a belief that China might follow Japan in its preference for local brands. In 1994 Shiseido launched the locally-made Aupres brand in China. It was positioned as being made especially for Chinese women, even if it had a French name, and was advertised by Chinese models rather than the Western models used for Shiseido’s imported brands. Aupres proved successful and was even adopted as the official brand for the Chinese Copyright $@ 2010$ by Geoffrey Jones

Working papers are in draft form. This working paper is distributed for purposes of comment and discussion only. It may not be reproduced without permission of the copyright holder. Copies of working papers are available from the author. 
team at the Athens Olympics in 2004. Yet over time more complex trends became apparent. Chinese consumers seemed to combine great enthusiasm for the aspirational nature of Westernsounding beauty brands with a growing desire for local relevance.

As a result, US and European multinationals experimented with Asian-specific executions of global platforms. Many Chinese consumers wanted to see Chinese faces as models, but there remained uncertainty within the industry about how far localization should be taken, and what form it should take. L’Oréal Paris, which had once only used white, preferably French, models, had four leading Chinese celebrities, including Gong Li and Zhang Ziyi, as spokes models by 2008, chosen in part to reflect the diversity of China's population. The localization of spokes models in China was only one aspect of the search for local relevance. Western companies employed local talent for photographical shoots as a means to getting greater local aesthetic sensitivity. Local ingredients were also featured in global brands, not as in the past for reasons of availability and cost, but to enhance their appeal. Chinese consumers wanted their Western shampoos to include black sesame and ginseng, or to have local herbs in their toothpaste. $^{64}$

There were new complexities, too, as multinationals seized opportunities to exploit the low cost labor of developing countries. The transfer of assembly facilities to low wage locations in developing countries, which were frequently free trade and low tax zones, had been pioneered by the semiconductor industry as long ago as the 1960s. South-east Asia and Mexico were the major locations; by the early 1990s some half a million Mexicans were employed in foreign Copyright $@ 2010$ by Geoffrey Jones

Working papers are in draft form. This working paper is distributed for purposes of comment and discussion only. It may not be reproduced without permission of the copyright holder. Copies of working papers are available from the author. 
multinational owned factories that assembled imported components for export, mostly located just over the border with the United States. Thereafter the shift of multinational production to China became a major trend, with considerable adverse consequences for South-east Asia and Mexico.

The off-shoring of services to developing countries also gained major momentum. In particular, the revolution in the speed of communications through the World Wide Web, satellites and optical fiber cables provided new opportunities for multinationals to reduce costs by locating parts of their value chain in developing countries by making outsourcing in information technology and offshore services feasible. ${ }^{65}$ The off-shoring of IT services from the United States to India which began in the 1980s drove the dramatic growth of Bangalore. However, the fact that such off-shoring remained small in quantitative terms, and highly concentrated in India, Ireland, Canada and Israel, which accounted for three-quarters of offshore services in 2009, also pointed to implementation difficulties. In particular, concerns about data confidentiality, and consumer resistance to having telephone enquiries about bills, bank accounts and travel routed through to people with different accents, even led some firms to reverse offshoring. The most serious risk to off-shoring, especially but not only in professional business services, was political hostility, and pressure on companies. By 2009 there was a wide range of both Federal and state legislative measures in the United States designed to restrict or discourage US firms engaging in off-shoring. ${ }^{66}$ 
During the second global economy, multinationals faced much more effective competition from locally-owned companies, at least in some developing countries. In pharmaceuticals, for example, Western and Japanese multinationals now encountered successful local companies in India and elsewhere. They were sometimes favored by policies of national preference in contracts and regulations, often out of concerns to provide their populations with cheaper drugs. Some firms in India and China in particular developed skills to manufacture lowcost versions of goods for mass markets. This so-called "frugal engineering" posed a major threat to the higher-cost structures of multinationals from developed countries. ${ }^{67}$ Only a few multinationals were able to develop production and marketing strategies which kept their costs down, and were capable of selling to the world's poorest at the "bottom on the pyramid". ${ }^{68}$ These included Unilever, which after experiencing the onslaught by Nirma pioneered strategies such as selling consumer products in small sachets which the very poor could buy, or the cell phone company Vodafone, which introduced mobile banking products aimed to facilitate access to basic financial services in Africa.

There were several drivers behind the growth of more competitive locally-owned firms in developing markets. The dynamics of the global economy lowered the barriers for new entrants from developing countries because of the disintegration of production systems and their replacement by networks of inter-firm linkages. The rapid growth of outsourcing and subcontracting to contract manufacturers created new opportunities for firms to grow. ${ }^{69}$ The growth of global capital markets made it much easier to raise funds, at least if a company was in a wellauthor. 
regarded country, such as India or Chile. The barriers to building managerial capabilities were reduced. Returning diaspora became important sources of managerial knowledge to Chinese and Indian firms. Both business schools and management consultants provided much easier access to new management knowledge, and assumed important roles in building organizational capabilities. The leaders of many of the largest firms in developing countries, such as Mexico's Cemex, were typically educated at leading American business schools.

Multinationals also served as role models and training grounds for local entrepreneurs to create their own businesses, and as sources of skilled staff. Typically locally-owned firms sought to differentiate themselves by selling products that were cheaper than multinational firms, and by emphazing their local identity and knowledge. They frequently had more difficulty expanding beyond their home economies, although by the new century a number were well-established as successful multinationals, such as Lenovo and Huawei in China, Cemex and Grupo Bimbo in Mexico, or Arcor in Argentina. ${ }^{70}$

Avon serves as an example of these processes. Avon inspired, and in some respects, paved the way for the creation of several important locally-owned competitors. These included Natura, which was founded in 1969 after Avon had already built a large business in the country. After a few years, Natura also adopted the direct selling business model, and grew rapidly during the "lost decade" of the 1980s, when the extreme economic instability resulted in many foreign companies leaving the country, and the collapse of most department stores, and their consequent elimination as a distribution channel. Natura was able to recruit thousands of sales Copyright (C) 2010 by Geoffrey Jones

Working papers are in draft form. This working paper is distributed for purposes of comment and discussion only. It may not be reproduced without permission of the copyright holder. Copies of working papers are available from the author. 
representatives who needed a source of income, and were attracted to the firm's growing commitment to environmental causes. Like a whole cluster of Brazilian companies, including Sabó in auto parts, Natura figured out how to management in the unpredictable and turbulent Brazilian environment. $^{71}$ In 2004 Natura, whose sales had reached \$1 billion, floated approximately $25 \%$ of its shares in an IPO, and two years later replaced Unilever as the market leader in Brazil. Despite its domestic size, Natura struggled to grow an international business. ${ }^{72}$

In Thailand, a local competitor was spawned directly from Avon, which had entered the country in 1978. Over the following decade the firm's annual sales grew from 39 million Thai baht to 400 million baht, with a workforce of 30,000 sales agents. In 1988 Amornthep Deerojanawong, the former manager of Avon in Thailand, established the Better Way (Thailand) Company, which three years later launched the Mistine brand of cosmetics. Aged 46 years old, he had come to the conclusion that "it was time to have his own business", especially as at that time the Thai economy was experiencing rapid growth. ${ }^{73}$ He was supported financially by his friend who owned the Saha Group, the country's largest consumer products company and a major retailer, and which manufactured the new cosmetics. Aware that Thai consumers believed that foreign products were always superior to local ones, Amornthep broke from normal practice in direct selling by using mass media television advertising, and made great play of using Thai actresses and actors to build the brand. He was also able to improve the logistics of his "sales cycle" - the process of issuing a new catalogue to a sales representative, presenting it to customers, and getting the order submitted - so Mistine had 26 cycles in a year rather than

Working papers are in draft form. This working paper is distributed for purposes of comment and discussion only. It may not be reproduced without permission of the copyright holder. Copies of working papers are available from the author. 
Avon's 18. ${ }^{74}$ By 2000 Mistine, despite experiencing a one-fifth fall in sales during the Asian financial crisis in 1997, had captured over half of the direct-selling market, with some 400,000 sales representatives. ${ }^{75}$

As local firms in emerging markets gained competitiveness, multinationals with strong proprietary technologies and well-regarded brands were best-placed to compete with local firms which were expert in frugal engineering. Strong technological advantages could also keep a company such as Cisco in business in a country such as China, where other things being equal, the government would prefer a local firm for strategic reasons. Multinationals with global design and product capabilities, such as Microsoft or Coca Cola, were also able to retain advantages competitive against local rivals, especially if their marketing and other strategies were able to combine their global capabilities with local relevance. Both Western and Japanese companies, whether Toyota in automobiles or Shiseido in cosmetics, were also able to build advantages in developing countries, especially China, by emphasizing that their products were of the highest quality and safe to both consumers and the environment.

\section{Conclusions}

In the first era of globalization, the strategies of multinationals in the developing world had been straightforward. They had sought access to their resources, and governments had frequently given them exclusive contracts and favorable deals in order to build businesses. Innovation had rested more in the area of execution - whether engineering feats, or building new organizational forms.

Copyright $@ 2010$ by Geoffrey Jones

Working papers are in draft form. This working paper is distributed for purposes of comment and discussion only. It may not be reproduced without permission of the copyright holder. Copies of working papers are available from the author. 
As the world de-globalized, the main challenges faced by multinationals were political. Mounting hostility led many firms to divest, and to invest elsewhere. The firms that remained needed to build political contacts with local governments, and attempt to strengthen their local identities, especially by localizing their managements. There was relatively little attempt to adjust products to markets, although the extension of the direct selling model to developing countries was important. There was also relatively little need to adjust to local competition.

In the contemporary global economy, political risks declined with the spread of liberalization and the abandonment of anti-foreign restrictions. There was no sudden reversion to the pre-1929 situation, however, and in such major emerging markets as China, corporate strategies needed to carefully manage relations with the government. There were also new types of political risk, including being sued in American courts for human rights abuses. Developing countries, or at least the larger and more fast-growing ones in Asia and Latin America, were increasingly seen as indispensable by multinationals in every industry. However there was a growing need in parts of the world to incorporate local relevance into global products, which was exactly the advantage of new, locally-owned firms, that were growing to scale, and becoming multinationals in their own right.

Working papers are in draft form. This working paper is distributed for purposes of comment and discussion only. It may not be reproduced without permission of the copyright holder. Copies of working papers are available from the author. 


\section{Bibliography}

Bader, M. B. (1980), "Breast-Feeding: The Role of Multinational Corporations in Latin America,” in K. Kumar (ed.) Transnational Enterprises: Their Impact on Third World Societies and Cultures (Boulder: Westview, 1980).

Bamberg, James H., The History of the British Petroleum Company, vol. 2. The Anglo-Iranian Years (Cambridge: Cambridge University Press, 1994).

Bamberg, James H. British Petroleum and Global Oil, 1950-1975. The Challenge of Nationalism (Cambridge: Cambridge University Press, 2000).

Barbero, María Inés, “La formación de grupos económicos en la Argentina contemporánea. El caso Arcor (1951-1990),” in Mario Cerutti (ed.) Empresas y grupos empresariales en América Latina, España y Portugal (Monterrey: Universidad Autónoma de Nuevo León, 2006).

Bonaglia, Frederico, Coplan, Asli M. and Goldstein, Andrea, "Innovation and internationalization in the white goods GVC: the case of Arçelik”, International Journal of Technological Learning, Innovation and Development, 1, 4 (2008).

Broughton, Edward, “The Bhopal Disaster and its Aftermath; A Review,” Environmental Health, 4, 6 (2005).

Brown, Rajeswary Ampalavanar, Chinese Big Business and the Wealth of Asian Nations(Basingstoke: Palgrave, 2000).

Copyright (C) 2010 by Geoffrey Jones

Working papers are in draft form. This working paper is distributed for purposes of comment and discussion only. It may not be reproduced without permission of the copyright holder. Copies of working papers are available from the author. 
Bucheli, Marcelo, Bananas and Business. The United Fruit Company in Colombia, 1899-2000 (New York: New York University Press, 2005).

Connell, Carol Matheson, A Business in Risk. Jardine Matheson and the Hong Kong Trading Industry (Wesport, Conn: Praeger, 2004).

Connolly, Priscilla, "Pearson and Public Works Construction in Mexico 1890-1910", Business History, 41, 1 (1999).

Corley, T.A.B. A History of the Burmah Oil Company 1886-1924 (London: Heinemann, 1983).

Cox, Howard, The Global Cigarette. Origins and Evolution of British American Tobacco 18801945 (Oxford: Oxford University Press, 2000).

Decker, Stephanie, “Corporate Legitimacy and Advertizing: British Companies and the Rhetoric of Development in West Africa, 1950-1970”, Business History Review 81 (Spring 2007), pp.5986.

Deerojanawong, Amornthep, Rao Pen Tee Nueng (We Are Number One) (Bangkok: S. Asia Press Co., 1989). In Thai.

Dunning, John H. and Lundan, Sairanna M., Multinational Enterprises and the Global Economy (Northampton, Mass: Edward Elgar, 2008).

Working papers are in draft form. This working paper is distributed for purposes of comment and discussion only. It may not be reproduced without permission of the copyright holder. Copies of working papers are available from the author. 
Duriez, Lale, "Ford in Turkey: From Imports to Partnership”, in Hubert Bonin, Yannick Lung and Steven Tolliday (eds), Ford. The European History 1903-2003, vol. 2 ( Paris: P.l.a.g.e, 2003), pp. 485-495.

Dyer, D., Dalzell, F. and Olegario, R., Rising Tide. Lessons from 165 Years of Brand Building at Procter \& Gamble (Boston: Harvard Business School Press, 2004).

Ferrier, R. W. The History of British Petroleum Company, Volume 1: The Developing Years, 1901-1932 (Cambridge: Cambridge University Press, 1982).

Fortanier, Fabienne and Tulder, Rob van, "Internationalization trajectories - a cross-country comparison: Are large Chinese and Indian companies different”, Industrial and Corporation Change, 18, 2 (2009).

Geddes, Charles F. Patiño, the tin king (London: R. Hale, 1972).

Giebelhaus, August W. "The Pause that refreshed the world. The Evolution of Coca-Cola's global marketing strategy”, in Geoffrey Jones and Nicholas J. Morgan (eds) Adding Value. Brands and Marketing in Food and Drink (London: Routledge, 1994), pp.191-214.

Guillen, Mauro F., "Is Globalization Civilizing, Destructive or Feeble? A Critique of Five Key Debates in the Social Science Literature”, Annual Review of Sociology (2001), pp. 235-260.

Gupta, Amar and Sao, Deth, "Anti-Offshoring Legislation and United States Federalism: The Constitutionality of Federal and State Measures Against Global Outsourcing of Professional Copyright (C) 2010 by Geoffrey Jones

Working papers are in draft form. This working paper is distributed for purposes of comment and discussion only. It may not be reproduced without permission of the copyright holder. Copies of working papers are available from the author. 
Services” Texas International Law Journal, www.allbusiness.com/government/us/123844271.html, accessed August 52009.

Hausman, William J., Hertner, Peter, and Wilkins, Mira, Global Electrification. Multinational Enterprise and International Finance in the History of Light and Power, 1878-2007 (Cambridge: Cambridge University Press, 2008).

Headrick, D.R. The Tentacles of Progress: Technology Transfer in the Age of Imperialism, 18591940 (Oxford: Oxford University Press, 1988).

Heer, J. ,World Events 1866-1966:The First Hundred Years of Nestlé (Rivaz: Nestlé, 1966).

Johanson, Jan and Vahlne, Jan-Erik, “The Uppsala internationalization process model revisited: From liability of foreignness to liability of outsidership”, Journal of International Business Studies, 40 (2009), 1411-1431.

Jones, Geoffrey, Banking and Empire in Iran (Cambridge; Cambridge University Press, 1986).

Jones, Geoffrey, Beauty Imagined. A History of the Global Beauty Industry (Oxford: Oxford University Press, 2010).

Jones, Geoffrey, “Learning to Live with Governments: Unilever in India and Turkey, 19501980,” Entreprises et Histoire, 49 (2007), 78-101.

Jones, Geoffrey, Merchants to Multinationals (Oxford: Oxford University Press, 2000).

Copyright $\odot 2010$ by Geoffrey Jones

Working papers are in draft form. This working paper is distributed for purposes of comment and discussion only. It may not be reproduced without permission of the copyright holder. Copies of working papers are available from the author. 
Jones, Geoffrey and Bucheli, Marcelo, "The Octopus and the Generals: The United Fruit Company in Guatemala”, Harvard Business School Case No 9-805-146 (XX)

Jones, Geoffrey and Bud-Frierman, Lisa, "Weetman Pearson and the Mexican Oil Industry”, Harvard Business School Case No. 9-804-085 (revised June 14, 2007).

Jones, Geoffrey and Kiron, David, “Cisco Goes to China: Routing an Emerging Economy”, Harvard Business School Case, 9-805-020 (revised February 25, 2008).

Jones, Geoffrey and Kiron, David, “Globalizing Consumer Durables: Singer Sewing Machines before 1914”, Harvard Business School Case No 9-804-001 (revised June 4, 2008).

Jones, Geoffrey and Reavis, Cate, "Multinational Corporations in Apartheid-era South Africa: The Issue of Reparations,” Harvard Business School Case, No 9-804-027 (revised July 8 2009).

Jones, Geoffrey, Multinationals and Global Capitalism (Oxford: Oxford University Press, 2005).

Jones, Geoffrey, Renewing Unilever. Transformation and Tradition (Oxford: Oxford University Press, 2005).

Jonker, Joost and Zanden, Jan Luiten van, From Challenger to Joint Industry Leader, 18901939. A History of Royal Dutch Shell, vol.1 (Oxford: Oxford University Press, 2007).

Kolk, Ans, "From Conflict to Cooperation: International Policies to Protect the Brazilian Amazon”, World Development, 26 (1998), 1481-93.

Copyright (C) 2010 by Geoffrey Jones

Working papers are in draft form. This working paper is distributed for purposes of comment and discussion only. It may not be reproduced without permission of the copyright holder. Copies of working papers are available from the author. 
Kumar, N, "Emerging MNCs: trends, patterns, and determinants of outward FDI by Indian enterprises”, in R. Rajan, R. Kumar and N. Virgill (eds.) New Dimensions of Economic Globalization (Singapore: World Scientific, 2008).

Lundan, Sarianna M. (eds) Multinationals, Environment and Global Competition (Amsterdam: Elsevier, 2004).

May, Stacy and Plaza, Galo, The United Fruit in Latin America (Washington: National Planning Association, 1958).

Monteith, Kathleen E.A. Depression to Decolonization. Barclays Bank (DCO) in the West Indies, 1926-1962 (Kingston: University of West Indies Press, 2008).

O’Rourke, Kevin and Williamson, Jeffrey G., Globalization and History (Cambridge, Mass, 1999).

Pananond, Pavida, “The making of Thai multinationals: A comparative study of Thailand's CP and Siam Cement groups”, Journal of Asian Business, 17, 3 (2001).

Phelps, Dudley Maynard Migration of Industry to South America (Westport, CT: Greenwood Press, 1939).

Piquet, C., “The Suez Company’s Concession in Egypt, 1854-1956: Modern Infrastructure and Local Economic Development”, Enterprise \& Society, 5, 1 (2004).

Copyright $\odot 2010$ by Geoffrey Jones

Working papers are in draft form. This working paper is distributed for purposes of comment and discussion only. It may not be reproduced without permission of the copyright holder. Copies of working papers are available from the author. 
Pomeranz, Kenneth, The Great Divergence. China, Europe and the Making of the Modern World Economy (Princeton: Princeton University Press, 2000).

Prahalad, C. K. The Fortune at the Bottom of the Pyramid (Upper Saddle River, NJ: Wharton School Publishing, 2005).

Schröter, Harm G. "Continuity and change: German multinationals since 1850”, in Geoffrey Jones and Harm G. Schröter (eds.), The Rise of Multinationals in Continental Europe (Aldershot: Edward Elgar, 1993).

Shapiro, Helen, Engines of Growth (Cambridge: Cambridge University Press, 1994).

Shepherd, Phil, "Transnational corporations and the denationalization of the Latin American cigarette industry,” in Alice Teichova, Maurice Lévy-Leboyer and Helga Nussbaum(eds) Historical Studies in International Corporate Business (Cambridge” Cambridge University Press, 1989).

Sluyterman, Keetie, Keeping Competitive in Turbulent Markets, 1973-2007. A History of Royal Dutch Shell (Oxford: Oxford University Press, 2007).

Stockwell, Sarah, The Business of Decolonization (Oxford: Oxford University Press, 2000).

Sull, Donald N. and Escobari, Martí, Success Against the Odds. What Brazilian champions teach us about thriving in unpredictable markets (Sao Paulo, 2004).

Copyright (C) 2010 by Geoffrey Jones

Working papers are in draft form. This working paper is distributed for purposes of comment and discussion only. It may not be reproduced without permission of the copyright holder. Copies of working papers are available from the author. 
Tignor, Robert, Capitalism and Nationalism at the end of Empire: State and Business in Decolonizating Egypt, Nigeria and Kenya, 1945-1963 (Princeton: Princeton University Press, 1998.)

United Nations Conference on Trade and Investment, World Investment Report 2008. Transnational Corporations and the Infrastructural Challenge (New York: UNCTAD, 2008).

White, Nicholas J., British Business in Post-Colonial Malaysia, 1957-70 (London: Routledge; Curzon, 2004).

Wilkins, Mira, The Emergence of Multinational Enterprise (Cambridge, Mass: Harvard University Press, 1970).

Williamson, Jeffrey G. "Globalization, Convergence, and History", Journal of Economic History, 56 (1996).

Williamson, Jeffrey G. "History without Evidence: Latin American Inequality since 1491", NBER Working Paper no 14766 (March 2009).

Wilson, Charles, The History of Unilever. A Study in Economic Growth \& Social Change (London: Cassel, 1954), vol.1.

Yach, Derek and Bettcher, Douglas, "Globalization of tobacco industry influences and new global responses,” Tobacco Control, 9 (2000), 206-218.

Working papers are in draft form. This working paper is distributed for purposes of comment and discussion only. It may not be reproduced without permission of the copyright holder. Copies of working papers are available from the author. 
Yacob, Shakila and White, Nicholas J., “The 'Unfinished Business' of Malaysia’s Decolonization: The Origins of the Guthrie 'Dawn Raid’”, Modern Asian Studies (forthcoming 2010).

*A first draft of this working paper was presented at the International Business History Conference held at Hitotsubashi University, Tokyo on January 8-10 2010. I am grateful for the comments of the participants, and especially Julia Yongue. Felipe Tâmega Fernandes also made valuable comments on a later draft.

${ }^{1}$ Guillen, “Is Globalization Civilizing.”

${ }^{2}$ Williamson, “Globalization”; O’Rourke and Williamson, Globalization and History.

${ }^{3}$ This periodization of globalization is based on Jones, Multinationals.

${ }^{4}$ Pomeranz, Great Divergence.

${ }^{5}$ Williamson, "History.”

${ }^{6}$ Wilson, Unilever, p.167-79.

${ }^{7}$ Connolly, “Pearson”.

${ }^{8}$ May and Plaza. The United Fruit; Bucheli, Bananas and Business.

${ }^{9}$ Hausman, et al, Global, chapters 2 and 3.

${ }^{10}$ Jones, Banking; Ferrier, History.

${ }^{11}$ For the importance of being an "insider" in business networks, see Johanson and Vahne, “The Uppsala”.

Copyright (C 2010 by Geoffrey Jones

Working papers are in draft form. This working paper is distributed for purposes of comment and discussion only. It may not be reproduced without permission of the copyright holder. Copies of working papers are available from the author. 
12 Jones, Merchants.

13 Jones, British Multinational Banking.

${ }^{14}$ Geddes, Patiño.

15 Jones, Merchants, pp. 57, 71-73; Connell, Business in Risk, pp.31-3.

16 The oil industry before 1914 saw constant failures, or near-death experiences. The Britishowned Shell Transport and Trading Company had to be taken over by Royal Dutch Petroleum Company. The Anglo-Persian only survived through support by Burmah Oil and the British government. Weetman Pearson's Mexican oil company accumulated large debts before oil was eventually found in 1909. See Jonker and Zanden, Challenger, chapter 1; Jones, Emergence, chapters 3 and 5; Corley, Burmah, pp. 95-111, 128-145, 181-198.

17 Jones and Bud-Frierman, “Weetman Pearson”.

18 Jones and Kiron, “Globalizing Consumer Durables.”

19 Jones, Merchants, chapter 6.

${ }^{20}$ Jones, British Multinational Banking, pp.83-92.

21 Jones, British Multinational Banking, p.17.

${ }^{22}$ Phelps, Migration.

${ }^{23}$ Headrick, Tentacles; Wilkins, Emergence, pp. 113-134.

${ }^{24}$ Piquet, “The Suez Company.”

${ }^{25}$ Kolk,” From Conflict.”

${ }^{26}$ Broughton, “The Bhopal disaster.”

Copyright (C) 2010 by Geoffrey Jones

Working papers are in draft form. This working paper is distributed for purposes of comment and discussion only. It may not be reproduced without permission of the copyright holder. Copies of working papers are available from the author. 
${ }^{27}$ Lundan (ed.), Multinationals.

${ }^{28}$ Schröter, “Continuity,” pp.40-42.

${ }^{29}$ Jones, British Multinational Banking, especially chapter 10.

${ }^{30}$ Jones, Merchants, pp.137-8.

${ }^{31}$ White, British.

${ }^{32}$ Yacob and White, “The 'Unfinished Business.””

33 Jones and Bucheli, “The Octopus”.

${ }^{34}$ Bamberg, History, chapter 18.

35 Monteith, Depression, chapter 9.

${ }^{36}$ Stockwell, Business; Tignor, Capitalism.

${ }^{37}$ Decker, “Corporate Legitimacy.”

38 Jones, Renewing, p.158.

${ }^{39}$ Dyer, Rising.

40 Jones, “Learning.”.

${ }^{41}$ Shapiro, Engines.

${ }^{42}$ Duruiz, ”Ford in Turkey.”

43 Jones, Merchants, chapter 6.

44 Jones, Multinationals, pp. 67-68; Jones, Renewing, pp.197-203.

45 Bamberg, British Petroleum, pp. 106-9, 185-215, 337-445; Keetie Sluyterman, Keeping Competitive, pp.13-95.

Copyright (C) 2010 by Geoffrey Jones

Working papers are in draft form. This working paper is distributed for purposes of comment and discussion only. It may not be reproduced without permission of the copyright holder. Copies of working papers are available from the author. 
46 Bader. "Breast Feeding."

${ }^{47}$ Cox, Global Cigarette.

48 Shepherd, “Transnational;” Yach and Bechtter, "Globalization of tobacco industry influence.”

49 Jones, Renewing, pp. 162- 169.

50 Heer, World Events; Jones, Renewing, pp. 192; Giebelhaus, “Coca-Cola’s global marketing strategy”, pp.208-9.

51 Jones, Beauty Imagined.

52 Jones, Beauty Imagined.

${ }^{53}$ Avon Archives, Hagley Museum, Delaware (hereafter AVON), Record Group I: Archive, Series 11: Avon International, Subseries B: Conferences, "Plans for Market Penetration - Puerto Rico,” International Division Merchandising Conference, March 1968, Box 69.

54 AVON, Avon Around the World, By Hays Clark, International Division, June 17-21 1963,

Box 124.

${ }^{55}$ AVON, “Avon Around the World.”

${ }^{56}$ AVON, “Avon Around the World.”

${ }^{57}$ AVON, “Avon Around the World.”

${ }^{58}$ Brown, Chinese, chapter 9; Pananond, “Making”.

59 Jones, Renewing, p.174.

60 Jones and Kiron, “Cisco”.

${ }^{61}$ Jones and Reavis, “Multinational Corporations”.

Copyright $@ 2010$ by Geoffrey Jones

Working papers are in draft form. This working paper is distributed for purposes of comment and discussion only. It may not be reproduced without permission of the copyright holder. Copies of working papers are available from the author. 
${ }^{62}$ Kenichi K. Ohmae, The Borderless World (New York: Harper Business, 1990); Thomas L.

Friedman, The World Is Flat (New York: Farrar, Straus and Giroux, 2005).

${ }^{63}$ Benjamin Barber, Jihad vs. McWorld. How Globalization and Tribalism Are Reshaping the World (New York: Times Books, 1995).

${ }^{64}$ Jones, Beauty Imagined.

${ }^{65}$ Jones, Multinationals, pp.34- 40.

${ }^{66}$ Gupta and Sao, “Anti-Off-shoring Legislation”.

${ }^{67}$ Kumar, "Emerging."

${ }^{68}$ Prahalad, Fortune.

${ }^{69}$ See for example Bonaglia, Coplan and Goldstein, "Innovation”.

${ }^{70}$ Barbero, “La Formación”; Fortanier and Tulder, “Internationalization trajectories.”

${ }^{71}$ Sull and Escobari, Success.

${ }^{72}$ Jones, Beauty Imagined.

${ }^{73}$ Amornthep Deerojanawong, Rao Pen Tee Nueng (We Are Number One) (Bangkok: S. Asia Press Co., 1989). In Thai, p. 35.

${ }^{74}$ Deerojanawong, Rao, pp. 114, 141-7.

${ }^{75}$ Jones, Beauty Imagined.

Working papers are in draft form. This working paper is distributed for purposes of comment and discussion only. It may not be reproduced without permission of the copyright holder. Copies of working papers are available from the author. 